\title{
A STUDY ON SUITABILITY OF WASTE TYRE RUBBER STABILIZED RED SOIL AS SUBGRADE MATERIAL
}

\section{Sumanjali Parimi $^{\# 1}$, Prof. P.V.V. Satyanarayana ${ }^{\# 2}$}

\#1 Asst. Prof, Department of Civil engineering, Raghu Institute of Technology, 9949946226, sumanjali.parimi676@gmail.com.

\#2 Professor, Department of Civil engineering, Andhra University college of engineering (A), Visakhapatnam.

\section{ABSTRACT:}

Soil stabilization means alteration of soil properties to meet the specified engineering requirements. Lime and cement was commonly used as stabilizer for altering the properties of soil. Earth reinforcements was commonly done using Geo synthetics. From the recent study it is observed that solid waste material such as waste tyre rubber is utilized for the intended purpose with or without lime and cement.

Now a days it is necessary to utilize the waste effectively with technical development in each field. The old abondedtyres from road vehicles are stockpiled throughout the country. This leads to various environmental problems which include air pollution associated with open burning of tyres, harmful contaminants and aesthetic pollution. There are non biodegradable and the waste tyre rubber has become a problem of disposal.

This project is intended to utilize the feasibility of worn out tyre rubber can be used as a stabilizing material for soil in pavements. The waste tyre rubber is mixed with soil in various percentages and carried out different tests results by forming normal and rubber stabilized soil and calculate various properties that may strengthen road pavement by achieving it economically. This not only minimizes the pollution occurred due to waste tyres but also the use of conventional aggregate which is available in exhaustible quantity.

Key words: soil stabilization, waste tyre material, pollution

\section{Corresponding Author:P. Sumanjali}

\section{INTRODUCTION}

Stabilization of soil is essential now a days due to scarcity of construction materials. If the stabilization is done by using some waste material, it is helpful in reusing and also reduces the cost of stabilization there by cost of construction.

In recent years, application of industrial wastes has been considered in the construction. One such material is Waste rubber tyrewhich is used as a pavement material, embankment fill and construction material because of its high strength and Elasticity. Many researches had been conducted on crumb rubber for its usage as a stabilizing agent in the design of pavement. Prasad Raju (2009) explained the performance of waste tyre rubber on model flexible pavement at Asian Research Publishing network. Humphrey D.N(1999) studied about the civil engineering applications of tyre shreds. Nickels W.L(1997) explained properties of different sized scrap tyres on grouting, soil improvement and geosynthetics.

In the present study, locally available Red soil is stabilized with optimum dosage of rubber by conducting various geotechnical tests and its suitability in terms of CBR is checked as a subgrade material. 
Objectives of Present Study:

The main objective of the present study is stabilization of locally available soils with a waste tyre material.

- To know the geotechnical Characterization of Red soil.

- To know the properties of waste tyre material regarding construction.

- To know the geotechnical properties of Red soil + Waste tyre mixes at various percentages of tyre material.

- Selecting an optimum dosage of waste tyre material and checking the suitability of it as a construction material

\section{MATERIALS}

RED SOIL

Red soil is hugely available in the city of Vizianagaram. Red soil is collected near SITAM - GVP Boys hostel, Vizianagaram at depth of $0.5 \mathrm{~m}$ below Ground surface. The samples are subjected to various tests to know their geotechnical characterization by knowing various properties. The tests conducted are Specific Gravity, Grain size analysis, liquid limit, plastic limit, shrinkage limit, IS light compaction tests, CBR test etc..

\section{WASTE TYRE MATERIAL}

Shredded rubber used in this study was procured from the local market.Shredded rubber pieces having a size of 10 to $15 \mathrm{~mm}$ length, $2 \mathrm{~mm}$ thickness are collected from scrap tyres. The steel reinforcement around the outer circle of the tyre is removed by using hexablade. The remaining part of the tyre cut in to the pieces. The specific gravity of the rubber is tested and the specific gravity, compaction and C.B.R tests are conducted on red soil added with shredded rubber.

\section{METHODOLOGY}

RED SOIL

Specific Gravity:

The specific gravity of red soil is determined by Pycnometer method. The sample is subjected to three trials with three different percentages of soil and water.

Table1. Specific gravity values Red Soil

\begin{tabular}{|c|c|}
\hline TRAIL 1 & 2.73 \\
\hline TRAIL 2 & 2.7 \\
\hline TRAIL 3 & 2.71 \\
\hline
\end{tabular}

\section{Grain Size Analysis:}

Grain size analysis of Red soil is done with Coarse sieves of sizes ranging from $4.75 \mathrm{~mm}$ $75 \mu$

Table2. Grain size distribution of Red Soil

\begin{tabular}{|l|l|l|}
\hline S.NO & SIEVE SIZE & \% FINER \\
\hline 1 & $4.75 \mathrm{~mm}$ & 98 \\
\hline 2 & $2 \mathrm{~mm}$ & 82 \\
\hline 3 & $1 \mathrm{~mm}$ & 67 \\
\hline 4 & $600 \mu$ & 59.5 \\
\hline 5 & $425 \mu$ & 50.5 \\
\hline 6 & $300 \mu$ & 41.5 \\
\hline 7 & $150 \mu$ & 11.5 \\
\hline 8 & $75 \mu$ & 1 \\
\hline 9 & pan & 0 \\
\hline
\end{tabular}




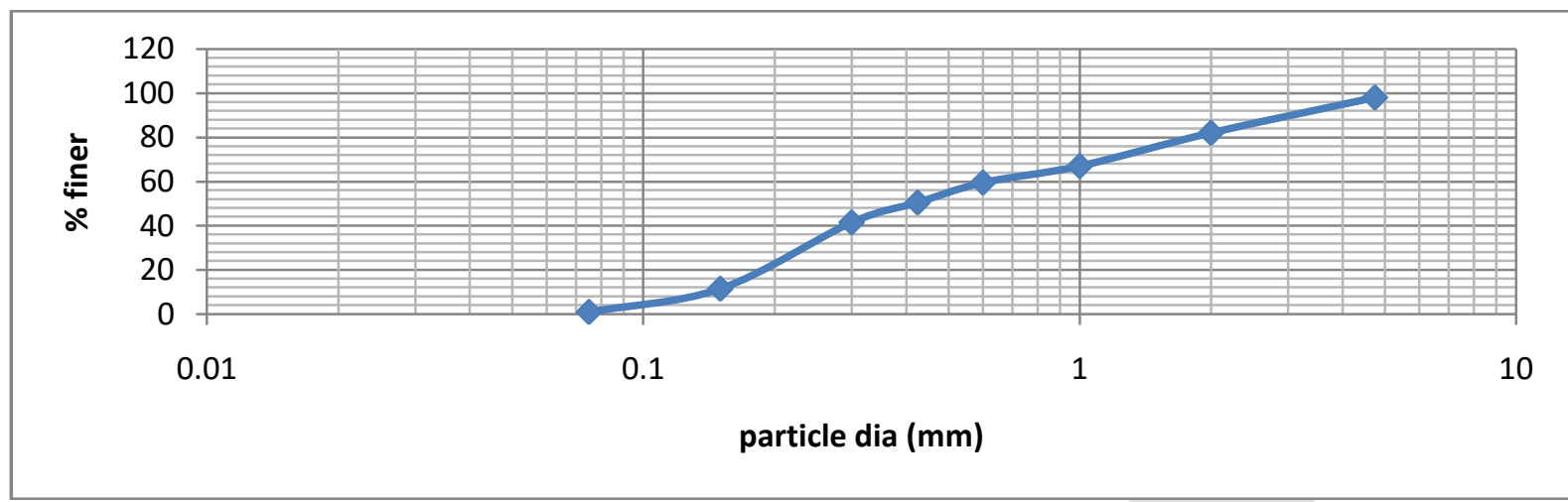

Fig : 1 Grain size distribution curve of Red Soil

From the test data, it is observed that the percentage finer through $4.75 \mathrm{~mm}$ sieve is $98 \%$, i.e sand sized particles. So, more than $50 \%$ is passing through $4.75 \mathrm{~mm}$ sieve, the sample is sand with $\mathrm{Cu}=5.0, \mathrm{Cc}=0.97$. For Well Graded Sand, $\mathrm{Cu}>6$ and $\mathrm{Cc}>1-3$. Therefore, the soil sample collected is Poorly Graded sand.

\section{Consistency limits:}

To know plasticity characteristics, Liquid limit and Plastic limit of Red soil sample are to be known. For that, Red soil passing through $425 \mu$ is tested.

Table3. Liquid limit of Red Soil

\begin{tabular}{|l|l|l|}
\hline & No. of blows & Water content (\%) \\
\hline Trail 1 & 20 & 25.46 \\
\hline Trail 2 & 36 & 23.94 \\
\hline Trail 3 & 40 & 22.59 \\
\hline Trail 4 & 78 & 20.5 \\
\hline
\end{tabular}

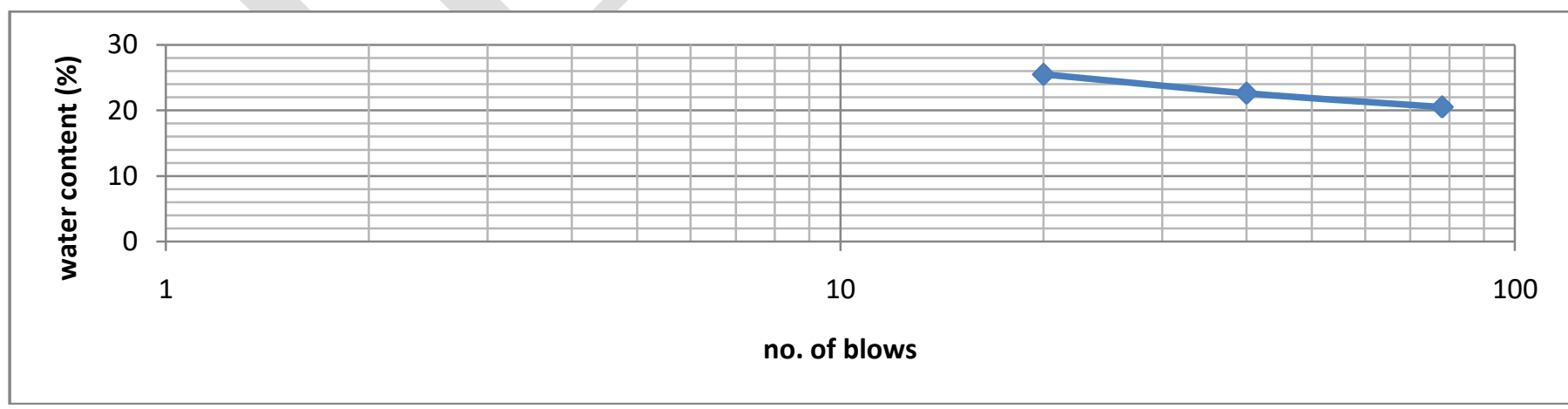

Fig : 2 Flow curve of Red Soil (Liquid limit curve)

From the Graph, Liquid limit is the water content at 25 number of blows i.e, $22 \%$

From the Experimental Data, Plastic limit $=15.15 \%$

Plasticity index $=$ Liquid limit - Plastic limit $=22-15.15=6.85 \%$

For Subgrade material, Plasticity index value should be less than or equal to 6 . Therefore the material can be used as a pavement material as it is having less Plasticity index. 


\section{Compaction Characteristics:}

The red soil is tested to know the compaction characteristics such as optimum moisture content and maximum dry density by the IS Light weight compaction method. In this method the red soil is compacted with $2.56 \mathrm{kgs}$ light weight rammer having a free fall of $350 \mathrm{~mm}$ in three layers.

Table4. Compaction characteristics of Red soil

\begin{tabular}{|c|c|c|}
\hline S.no & Moisture content $(\%)$ & Dry density $(\mathrm{g} / \mathrm{cc})$ \\
\hline 1 & 6 & 1.825 \\
\hline 2 & 8 & 2.014 \\
\hline 3 & 10 & 2.122 \\
\hline 4 & 12 & 2.080 \\
\hline 5 & 14 & 2.055 \\
\hline
\end{tabular}

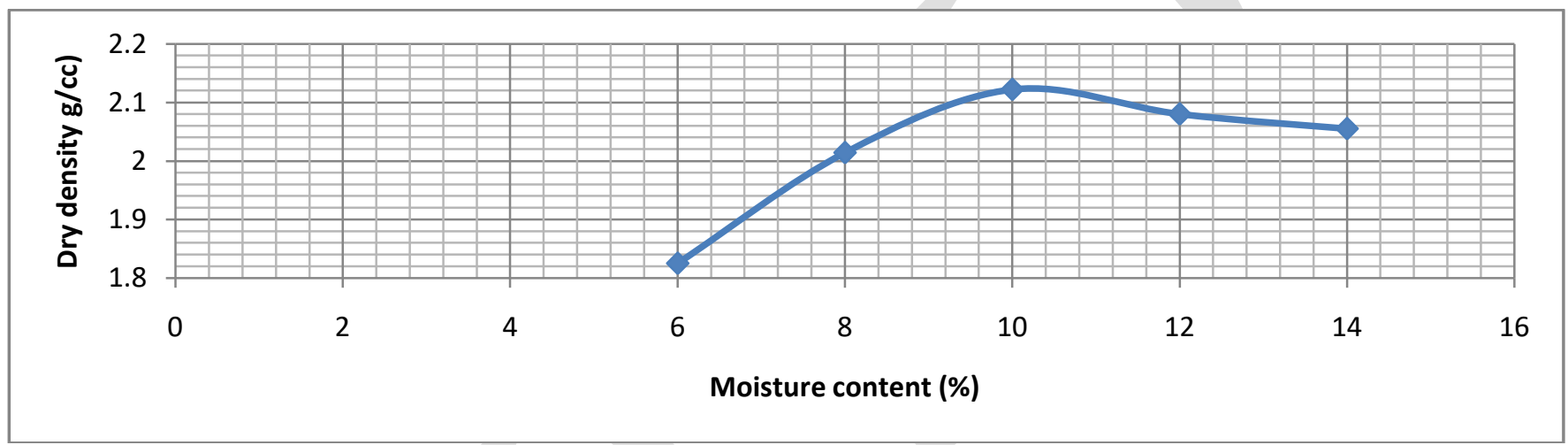

Fig : 3 curve of Red Soil Compaction

From the above graph we are observed that the maximum dry density occurred at $2.13 \mathrm{~g} / \mathrm{cc}$ of $10.5 \%$ optimum moisture content for the red soil.

\section{Strength Characteristics:}

The red soil is subjected to compaction as per IS Heavy weight compaction method and used to determine C.B.R value of the red soil by using C.B.R apparatus. In IS heavy weight compaction method the red soil compacted in five layers with a $4.56 \mathrm{kgs}$ heavy weight rammer having a free fall of $410 \mathrm{~mm}$.

Table5. Strength Characteristics of soil

\begin{tabular}{|c|c|c|}
\hline Penetration $(\mathrm{mm})$ & Proving ring reading & Load $(\mathrm{kN})$ \\
\hline 0 & 0 & 0 \\
\hline 50 & 0.1 & 0.025 \\
\hline 100 & 0.6 & 0.15 \\
\hline 150 & 1.4 & 0.35 \\
\hline 200 & 2 & 0.5 \\
\hline 250 & 3 & 0.75 \\
\hline 300 & 3.4 & 0.85 \\
\hline 400 & 4 & 1 \\
\hline 500 & 4.8 & 1.2 \\
\hline 600 & 5.5 & 1.375 \\
\hline 700 & 6.9 & 1.72 \\
\hline 800 & 7.8 & 1.95 \\
\hline 900 & 8.8 & 2.2 \\
\hline 1000 & 9.6 & 2.4 \\
\hline
\end{tabular}




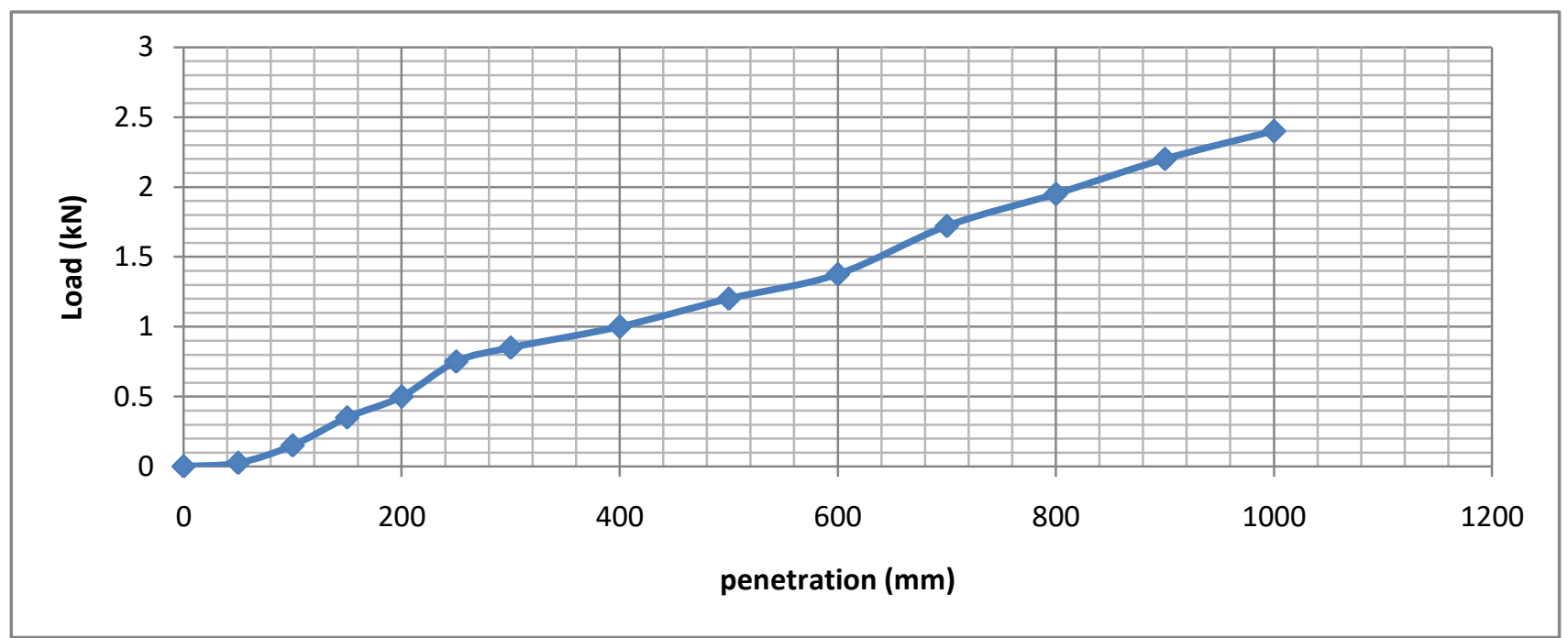

Fig: 4 CBR curve of the Red soil

From Graph, initially the graph is in concave shape after the correction applied for the graph it meets the $x$-axis at 0.65 . so the origin is shifted to 0.65 now the load at $2.5 \mathrm{~mm}$ penetration is 0.9 instead of 0.75 , load at $5 \mathrm{~mm}$ penetration is 1.3 instead of 1.2 as mentioned in the table.

$\mathrm{CBR}$ value at $2.5 \mathrm{~mm}$ penetration $=(\operatorname{Load}$ at $2.5 \mathrm{~mm}$ penetration in $\mathrm{kN} / 13.50) * 100$

$$
\begin{aligned}
& =(0.9 / 13.50) * 100 \\
& =6.67 \%
\end{aligned}
$$

$\mathrm{CBR}$ value at $5.0 \mathrm{~mm}$ penetration $=($ Load at $5.0 \mathrm{~mm}$ penetration in $\mathrm{kN} / 20.55) * 100$

$$
\begin{aligned}
& =(1.3 / 20.55)^{*} 100 \\
& =6.32 \%
\end{aligned}
$$

Summary of results of Red soil:

\begin{tabular}{|l|l|l|}
\hline S. No & Geotechnical property & Results \\
\hline 1 & Specific gravity & 2.71 \\
\hline 2 & Grain size analysis & $\begin{array}{l}\mathrm{Cu}=5 \\
\mathrm{Cc}=0.98\end{array}$ \\
\hline 3 & Liquid limit & $21 \%$ \\
\hline 4 & Plastic limit & $15.15 \%$ \\
\hline 5 & Plasticity index & $5.85 \%$ \\
\hline 6 & Optimum moisture content & $10.5 \%$ \\
\hline 7 & Maximum dry density ratio & $2.13 \mathrm{~g} / \mathrm{cc}$ \\
\hline 8 & $\begin{array}{l}\text { California bearing } \\
\text { Soaked) }\end{array}$ \\
\hline
\end{tabular}

From the test results of Red soil collected at Vizianagaram, it is observed that the material available is a poorly graded material having $\mathrm{Cu}=5$ and $\mathrm{Cc}=0.98$. the specific gravity of the material is also quite good. From the Atterberg limits data, plasticity index is also quite low i.e, $5.85 \%$. Therefore the material can be used as a pavement and construction material. But the soaked CBR value of the soil is very less. To improve the soil in strength aspect, the soil is stabilized by is waste rubber tyre material extracted from worn out tyres of material which is hugely available in the open scrap market. The soil is stabilized with different percentages of 2, 4, 6 and 8 by the dry weight of Red soil. 


\section{Shredded rubber:}

\section{Specific gravity of shredded rubber:}

Three different samples of shredded rubber are taken in three trails to know the specific gravity of the shredded rubber by the pycnometer method.

Table 6. specific gravity of shredded rubber

\begin{tabular}{|c|c|}
\hline Trail 1 & 1.12 \\
\hline Trail 2 & 1.131 \\
\hline Trail 3 & 1.130 \\
\hline
\end{tabular}

From the above table the average specific gravity of shredded rubber is 1.13

Specific gravity of red soil added with various percentages shredded rubber:

400 grams of red soil and different percentage of shredded rubber are taken to know the specific gravity by the pycnometer method. The rubber percentage is taken as $2,4,6,8$ and $10 \%$ for the five trails.

Table7. Specific gravity of Red soil added with various percentages shredded rubber

\begin{tabular}{|c|c|c|}
\hline S. no & \% Rubber & Specific gravity \\
\hline 1 & 2 & 2.58 \\
\hline 2 & 4 & 2.56 \\
\hline 3 & 6 & 2.5 \\
\hline 4 & 8 & 2.37 \\
\hline 5 & 10 & 2.36 \\
\hline
\end{tabular}

Compaction characteristics of the red soil added with shredded rubber:

The red soil added with different percentage of shredded rubber are compacted by the IS Light weight compaction method to know the optimum moisture content and maximum dry density.

Table8. Compaction characteristics of the red soil added with shredded rubber

\begin{tabular}{|l|l|l|l|}
\hline s. no & \% Rubber & OMC $(\%)$ & MDD $(\mathrm{g} / \mathrm{cc})$ \\
\hline 1 & 2 & 10.9 & 2.110 \\
\hline 2 & 4 & 11.2 & 1.995 \\
\hline 3 & 6 & 11.8 & 1.85 \\
\hline 4 & 8 & 12.5 & 1.77 \\
\hline
\end{tabular}

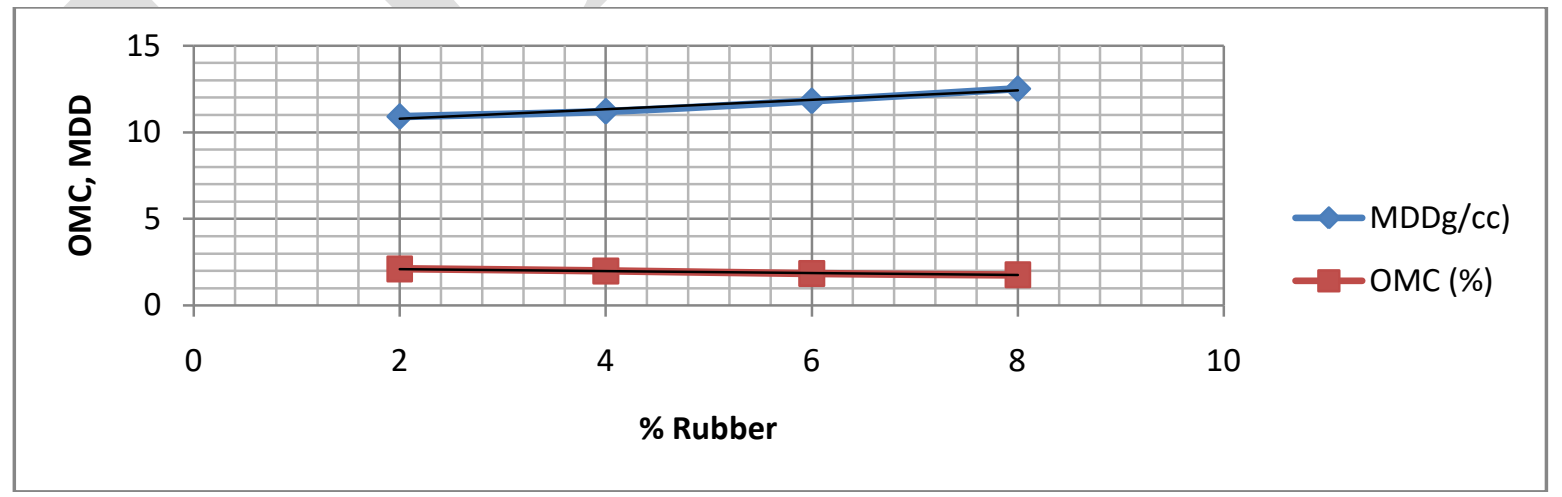

Fig : 5 Comparison of Compaction Characteristics of Red soil added with shredded rubber

From the test data of Red soil + Shredded rubber mixes at various percentages, it is clearly observed the mix OMC is increasing gradually and MDD is decreasing due light weight rubber replacement. At higher percentages i.e, 6 and 8 percentage, the mix becomes lighter in weight. Therefore the soaked CBR values of the mixes are determined at a percentage of 2 and 4 percentage. 


\section{California bearing ratio of the red soil added with the shredded rubber:}

The red soil added with 2 and $4 \%$ of the shredded rubber and compacted as per standard CBR test procedure in C.B.R mould and is soaked for 3 days and tested to know the C.B.R value.

Table9. Strength characteristics of the Red soil added with shredded rubber at 2 and 4 percentages

\begin{tabular}{|c|c|c|c|c|}
\hline Penetration $(\mathrm{mm})$ & PRR at $2 \%$ & Load $(\mathrm{kN})$ At $2 \%$ & PRR at $4 \%$ & Load $(\mathrm{kN})$ At $4 \%$ \\
\hline 0 & 0 & 0 & 0 & 0 \\
\hline 50 & 2.6 & 0.65 & 4.8 & 1.2 \\
\hline 100 & 3.2 & 0.8 & 5.6 & 1.4 \\
\hline 150 & 4.0 & 1 & 6.4 & 1.6 \\
\hline 200 & 5.2 & 1.3 & 9.6 & 2.4 \\
\hline 250 & 6.8 & 1.7 & 11.4 & 2.85 \\
\hline 300 & 7.2 & 1.8 & 13.8 & 3.45 \\
\hline 400 & 8.0 & 2 & 15.4 & 3.85 \\
\hline 500 & 9.5 & 2.375 & 16.8 & 4.2 \\
\hline 600 & 10.4 & 2.6 & 18 & 4.5 \\
\hline 700 & 12.0 & 3 & 20.8 & 5.2 \\
\hline 800 & 14.4 & 3.6 & 23.2 & 5.8 \\
\hline 900 & 16.8 & 4.2 & 25.8 & 6.45 \\
\hline 1000 & 19.0 & 4.75 & 28.2 & 7.05 \\
\hline
\end{tabular}

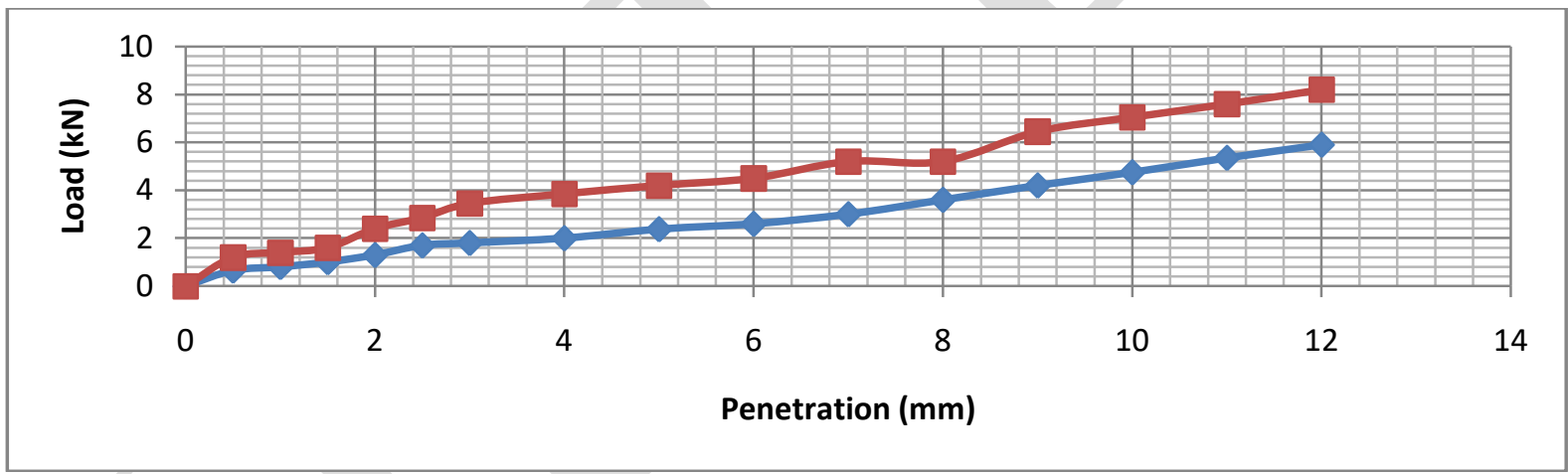

Fig : 6 C.B.R curve of the Red soil added with $2 \%$ and $4 \%$ shredded rubber

For Red soil $+2 \%$ Shredded Rubber,

$\mathrm{CBR}$ value at $2.5 \mathrm{~mm}$ penetration =

(Load at $2.5 \mathrm{~mm}$ penetration in $\mathrm{kN} / 13.50) * 100$

$$
\begin{aligned}
& =(1.7 / 13.50)^{*} 100 \\
& =12.6 \%
\end{aligned}
$$

$\mathrm{CBR}$ value at $5.0 \mathrm{~mm}$ penetration $=$

$($ Load at $5.0 \mathrm{~mm}$ penetration in $\mathrm{kN} / 20.55) * 100$

$$
\begin{aligned}
& =(2.375 / 20.55) * 100 \\
& =11.5 \%
\end{aligned}
$$

For Red soil $+4 \%$ Shredded Rubber,

$\mathrm{CBR}$ value at $2.5 \mathrm{~mm}$ penetration =

(Load at 2.5mm penetration in $\mathrm{kN} / 13.50) * 100$

$$
\begin{aligned}
& =(2.85 / 13.50) * 100 \\
& =21.11 \%
\end{aligned}
$$


CBR value at $5.0 \mathrm{~mm}$ penetration $=$

(Load at 5.0mm penetration in $\mathrm{kN} / 20.55) * 100$

$$
\begin{aligned}
& =(4.2 / 20.55)^{*} 100 \\
& =20.43 \%
\end{aligned}
$$

Summary of results of Red soil + various percentage of Shredded Rubber:

\begin{tabular}{|l|l|l|l|}
\hline S.no & Geotechnical property & $\begin{array}{l}\text { Red soil }+2 \% \\
\text { Shredded rubber }\end{array}$ & $\begin{array}{l}\text { Red soil + 4\% } \\
\text { Shredded rubber }\end{array}$ \\
\hline 1 & Specific gravity & 2.58 & 2.56 \\
\hline 2 & Compaction characteristics & & \\
& OMC (\%) & 10.9 & 11.2 \\
& MDD $(\mathrm{g} / \mathrm{cc})$ & 2.110 & 1.995 \\
\hline 3 & CBR (soaked) & 12.6 & 21.11 \\
& At 2.5 mm penetration & 11.5 & 20.43 \\
\hline
\end{tabular}

From the test results of Red soil + shredded rubber, it is very clear that the CBR value in soaked condition is increased 2 times with the addition of $2 \%$ Rubber and the value increases nearly 4 times with the addition of $4 \%$ Rubber. As the material posses high elasticity, it can easily transfer loads from one layer to another layer. The material also satisfies the MORTH specifications in the plasticity and Strength criteria. Therefore the stabilized material can be used as a pavement material in case of Flexible material.

\section{CONCLUSIONS}

1. Shredded rubber is light weight material having no permeability and having the good compressibility and high elasticity it can be used as stabilizing material for the soil.

2. Increasing the percentage of rubber decreases the specific gravity and density of Red soil and the optimum moisture content is increased when soil is added with rubber.

3. $2 \%$ of the shredded rubber is required for Red soil to improve the California bearing ratio of 2 times to suit as subgrade material and $4 \%$ of Shredded rubber is required for Red soil to improve CBR value 4 times to meet the higher load requirements.

4. Stabilized Red soil with an amount of $2 \%$ and $4 \%$ shredded rubber can be used effectively for the subgrade material of the pavement.

5. And the material also having less weight, so that in can be used in embankments. The factor of safety is also increasing with the addition of rubber.

\section{REFERENCES}

1. IS 1498-1970 - classification \& Identification of soil for general Engineering purposes.

2. IS 2270 (part 5) - 1985 - Methods of test for soil Determination of Liquid \& plastic limit.

3. IS 2720 (part 7) - 1980 - Methods of test for soil Determination of water content - Dry density relation using light compaction.

4. IS 2720 (part 10) - 1973 - Methods of test for soil Determination of unconfined compression strength.

5. Ajay, K., and Jawaid, S.M. (2013) "Soil Modification Using Shredded Scrap Tires". International Journal of Biological Sciences \& Technological Research (IJBSTR) Research Papers, Vol. 1, pp.10-13.

6. Amin, E.R. (2012) "A Review on the Soil Stabilization Using Low-Cost Methods". Journal of Applied Sciences Research, pp.2193-2196. 
7. Ayothiraman, R., and Abilash, M. (2011) "Improvement of subgrade soil with shredded waste tyre chips". Proceedings of Indian Geotechnical Conference Kochi, Paper no H -033 , pp.365-368.

8. Gary J. Foose., Craig H. Benson., and Peter J. Bosscher.(1996) "Sand Reinforced with shredded waste Tires". Journals of Geotechnical Engineering, pp 760-767.

9. Ghatge Sandeep Hambirao., and Rakaraddi, P.G. (2014) "Soil Stabilization Using Waste Shredded Rubber Tyre Chips". Journal of Mechanical and Civil Engineering (JMCE), Vol. 11,pp.20-27. 